\title{
ON MONOTONICITY OF SOME OPERATOR FUNCTIONS RELATED TO ORDER PRESERVING OPERATOR INEQUALITIES
}

\section{TATSUyA KoIZUmi And KeIICHI WATANABE}

Abstract. In this paper, we shall show an equivalence relation between extensions of order preserving operator inequalities and monotonicity of related operator functions.

Mathematics subject classification (2010): 47A63.

Keywords and phrases: Löwner-Heinz inequality, Furuta inequality, order preserving operator inequality.

\section{REFERENCES}

[1] T. FuRUTA, $A \geqslant B \geqslant 0$ assures $\left(B^{r} A^{p} B^{r}\right)^{1 / q} \geqslant B^{(p+2 r) / q}$ for $r \geqslant 0, p \geqslant 0, q \geqslant 1$ with $(1+2 r) q \geqslant$ $p+2 r$, Proc. Amer. Math. Soc. 101, 1 (1987), 85-88.

[2] T. FurUtA, Two operator functions with monotone property, Proc. Amer. Math. Soc. 111, 2 (1991), 511-516.

[3] T. FuRUTA, Extension of the Furuta inequality and Ando-Hiai log-majorization, Linear Algebra Appl. 219 (1995), 139-155.

[4] T. FURUTA, Further extension of an order preserving operator inequality, J. Math. Inequal. 2 (2008), $465-472$.

[5] T. FURUTA, Operator functions on chaotic order involving order preserving operator inequalities, to appear in J. Math. Inequal.

[6] T. Furuta, M. Hashimoto AND M. ITO, Equivalence relation between generalized Furuta inequality and related operator functions, Sci. Math. 1, 2 (1998), 257-259.

[7] T. FURUTA AND D. WANG, A decreasing operator function associated with the Furuta inequality, Proc. Amer. Math. Soc. 126, 8 (1998), 2427-2432.

[8] T. Furuta, T. YAMAZAKI AND M. YANAGIDA, Operator functions implying generalized Furuta inequality, Math. Inequal. Appl. 1 (1998), 123-130.

[9] T. FuRUTA, T. YAMAZAKI AND M. YANAGIDA, Order preserving operator inequalities via Furuta inequality, Math. Japon. 48 (1998), 471-476.

[10] E. HeinZ, Beiträge zur Störungstheorie der Spektralzerlegung, Math. Ann. 124 (1951), 415-438.

[11] M. ITO, M. HASHImOTO AND T. FURUTA, Equivalence relation between an order preserving operator inequality and related operator functions, Surikaisekikenkyusho Kokyuroku No. 1080 (1999), $34-40$.

[12] T. KoIZUMI AND K. WATANABE, A remark on extension of order preserving operator inequality, to appear in J. Math. Inequal.

[13] K. LÖWNER, Über monotone Matrixfunktionen, Math. Z. 38 (1934), 177-216.

[14] M. Uchiyama, Some exponential operator inequalities, Math. Inequal. Appl. 2 (1999), 469-471. 